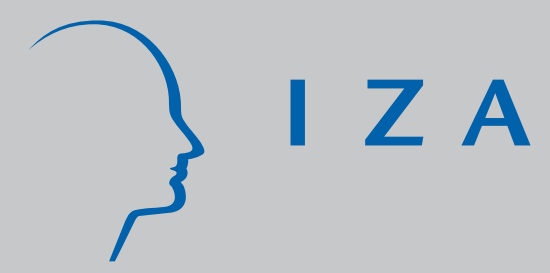

IZA DP No. 6408

Health Behavior and Accident Risk:

Obesity Is Associated with the Future Risk of Heavy Truck

Crashes among Newly Recruited Commercial Drivers

Jon E. Anderson Manjari Govada Tricia K. Steffen

Chris P. Thorne
Vasileia Varvarigou

Stefanos N. Kales

Stephen V. Burks

March 2012 


\title{
Health Behavior and Accident Risk: Obesity Is Associated with the Future Risk of Heavy Truck Crashes among Newly Recruited Commercial Drivers
}

\author{
Jon E. Anderson \\ University of Minnesota, Morris \\ Manjari Govada \\ University of Minnesota, Morris \\ Tricia K. Steffen \\ University of Minnesota, Morris \\ Chris P. Thorne \\ University of Minnesota, Morris
}

\author{
Vasileia Varvarigou \\ Harvard School of Public Health \\ and Harvard Medical School \\ Stefanos N. Kales \\ Harvard School of Public Health \\ and Harvard Medical School
}

Stephen V. Burks

University of Minnesota, Morris, CTS and IZA

Discussion Paper No. 6408

March 2012

\author{
IZA \\ P.O. Box 7240 \\ 53072 Bonn \\ Germany \\ Phone: +49-228-3894-0 \\ Fax: +49-228-3894-180 \\ E-mail: iza@iza.org
}

\begin{abstract}
Any opinions expressed here are those of the author(s) and not those of IZA. Research published in this series may include views on policy, but the institute itself takes no institutional policy positions.

The Institute for the Study of Labor (IZA) in Bonn is a local and virtual international research center and a place of communication between science, politics and business. IZA is an independent nonprofit organization supported by Deutsche Post Foundation. The center is associated with the University of Bonn and offers a stimulating research environment through its international network, workshops and conferences, data service, project support, research visits and doctoral program. IZA engages in (i) original and internationally competitive research in all fields of labor economics, (ii) development of policy concepts, and (iii) dissemination of research results and concepts to the interested public.
\end{abstract}

IZA Discussion Papers often represent preliminary work and are circulated to encourage discussion. Citation of such a paper should account for its provisional character. A revised version may be available directly from the author. 


\section{ABSTRACT}

\section{Health Behavior and Accident Risk: Obesity Is Associated with the Future Risk of Heavy Truck Crashes among Newly Recruited Commercial Drivers}

This study estimates the dose-response relationship between Body Mass Index (BMI) and crash risk in commercial motor vehicle operators. Intake data was collected on 744 new truck drivers who were training for their commercial driver's licenses at a school operated by the cooperating trucking firm during the first two-week phase of instruction. Drivers were then followed prospectively on the job using the firm's operational data for two years, or until employment separation, whichever came first. Multivariate Poisson regression and Cox proportional hazards models were used to estimate the relationship between crash risk and $\mathrm{BMI}$, controlling for exposure using miles driven, trip segments, and job type. Results from the Poisson regression indicated that the risk ratio (RR) for all crashes was significantly higher for drivers in the obesity Class II and Class III categories: $R R=1.6$, confidence interval 1.2-2.1 and $\mathrm{RR}=1.49$, confidence interval 1.12-1.99, respectively. Similarly, the multivariate Cox Proportional Hazard model results showed that crash risk was significantly higher for obesity class II (BMI 35 to $<40$; relative risk $(R R)=1.47, P=0.02)$ with weaker evidence of increased crash risk for obesity class III $(B M I>40 ; R R=1.35, P=0.06)$ when compared to normal BMI (BMI 18.5 to <25). The results of this prospective study establish an association between obesity and crash risk show that driver health behavior has important spillovers for public safety.

\section{NON-TECHNICAL SUMMARY}

We studied the relationship between the body mass index of newly recruited trainee truckers and their later on-the-job accident rate, controlling for job differences that affect the degree to which each driver is exposed to the risk of an accident. We find evidence that drivers who are very obese (WHO Class II and III, with BMI > 35) when entering this occupation have about a $50 \%$ a higher risk of an accident after training than do drivers of normal weight. Most accidents new drivers have are minor, but we also find that having a minor accident predicts a greater risk of a more serious one later. The cooperating firm operates in a high turnover part of the driver labor market, and new drivers are always a significant fraction of the work force at firms like this one. This suggests that driver health behavior (in this case before training) has significant spillovers to public safety.

JEL Classification: I12, J49, R41

Keywords: body mass index, obesity, traffic accidents, commercial motor vehicle, heavy truck, Poisson regression, Cox proportional hazard, truckload

Corresponding author:

Stephen V. Burks

University of Minnesota, Morris

Division of Social Sciences

600 East 4th Street

Morris, MN 56267-2134

USA

E-mail: svburks@morris.umn.edu 
1. INTRODUCTION

It is well known that the prevalence of obesity among US adults has more than doubled in recent decades (Flegal et al. 2010). Similar trends have been documented worldwide, and such increases are expected to continue (WHO 2000, Finucane et al. 2011). Additionally, because of obesity's contribution to diabetes mellitus (Eckel et al. 2011), cardiovascular disease, and certain cancers, the obesity epidemic's projected negative public health consequences on morbidity and mortality trends are frequently discussed (Calle et al. 2003, Berrington de Gonzalez et al. 2010).

On the other hand, the potential impact of increasing obesity on public safety has received considerably less attention. Because of robust associations with obstructive sleep apnea (OSA), excessive daytime sleepiness (EDS), and fatigue, (Vgontzas et al. 1998, TeranSantos et al. 1999, Philip 2005, Vgontzas 2008b) obesity could present significant risks during the performance of complex tasks such as driving trucks, piloting aircraft, operating public transit vehicles, and similar operational activities found in several transportation modes that require constant attention and vigilance (Dinges et al. 1997, Dagan et al. 2006, Cohen et al. 2010). If this hypothesis were true, even a small increase in risk would have a major impact on the population-attributable risk, given the frequent role of fatigue in crashes and the high prevalence of obesity (Dixon et al. 2007). For example, the Institute of Medicine (IOM) has estimated that nearly 20 percent of all serious injuries caused by motor vehicle crashes are related to drowsy driving (Garbarino et al. 2001). Similarly, the National Transportation Safety Board (NTSB) concluded that more that 30 percent of fatal-to-the-driver truck crashes are fatigue related (NTSB 1999). Moreover, obesity is present in as many as $50 \%$ of commercial drivers (Gurubhagavatula 2010). Thus, any additional risk due to obesity would have enormous policy consequences for the transportation industry and society at large.

One area that has received increasing interest from government regulators and investigators in occupational and sleep medicine is the association of obesity with OSA (Pack et al. 2006, Tregear et al. 2009). OSA is common among commercial drivers; with prevalence estimated as high as 17-28\% (Pack et al. 2002, Talmage et al. 2008, Parks et al. 2009); and a number of BMI-based, driver screening strategies have been proposed (Gurubhagavatula et al. 
2004, Hartenbaum et al. 2006). Working conditions in firms operating in the "truckload" (TL) segment of for-hire motor carriage (Burks et al. 2010), like that cooperating in this study, are particularly conducive to irregular rest and significant and persistent levels of driver fatigue. Driving for a TL firm involves serving different customers in different locations spread across the country, with varying trip origins and destinations, changing congestion and weather conditions, restrictions on behavior due to hours of service, route, and fueling rules, limited and uncertain time at home, and the expectation that drivers on the road live in their sleeper bunks (Burks et al. 2008). Together these factors generate pressure towards long work hours per day and per week that come at varying times of the day and night, and towards insufficient and irregular sleep. In fact, it is the ability of an individual to effectively manage his or her work life under these conditions that is the largest single predictor of success in this specific occupation (Burks 2009b, Burks 2009a). However, while studies in the general population have documented a two to seven-fold increase in motor vehicle accidents among persons with untreated OSA, these results have not been replicated reliably in commercial truckers (Pack et al. 2002).

A less appreciated, but equally important concern is that the obesity epidemic may be an important underlying cause of an increasing prevalence of fatigue and excessive daytime sleepiness (EDS) in the general population (Vgontzas 2008b, a). Accumulating evidence in the field supports the notion that through inflammatory pathways and mechanisms, visceral adiposity, insulin resistance and neuro-hormonal signaling, obesity plays a major role in the pathogenesis of sleep apnea as well as excessive daytime sleepiness. Although EDS is one of the main symptoms of OSA in clinical practice, obese patients without OSA can also present with EDS (Vgontzas et al. 1998).

Therefore, given obesity's significant associations with obstructive sleep apnea (OSA), excessive daytime sleepiness (EDS) and fatigue, in this prospective study, we examined the risk of truck crashes as a function of BMI among newly recruited professional drivers, statistically controlling for relevant factors that affect on-the-job exposure to accident risk. 


\section{MATERIaLS AND MethodS}

\subsection{STUDY PARTICIPANTS}

Firms of the type cooperating with this study, truckload for-hire motor carriers, historically have a significantly higher turnover rate than trucking firms of other types, reported by the American Trucking Associations to average more than 100 per cent per year until the recent economic recession (Economic and Statistics Group 2007, Watson 2009). Thus a significant fraction of drivers in this segment of the industry are always new hires, which makes new-to-the-industry trainees a relevant study population. One thousand sixty five new drivertrainees were eligible for the study over the period from December 2005 through August 2006, which was conducted as part of the Truckers \& Turnover Project, a larger ongoing behavioral economics research program (a more complete description of the context and overall design of data collection may be found in Burks, et al. (2008)). Data about participants was collected at a school operated by the cooperating firm in the middle of a two-week residential training programs. All participants were compensated for their time and participation in collection of intake data, and there was $91 \%$ participation rate among eligible trainees.

Of the 952 drivers that completed training and spent at least one week on the road, we have the BMI values for 744 participants. ${ }^{1}$ Drivers completing training were then followed prospectively on the job using the firm's human resource and operational data for two years, or until an employment separation, whichever came first. Drivers self-reported their heights and weights during initial intake via a computerized demographic survey that each driver completed privately. ${ }^{2}$ Heights were self-reported to the nearest inch \pm 0.5 inches between five feet, zero inches and six feet, six inches; and weights were self-reported to the nearest pound \pm 10 pounds between 100 and 350 pounds by selecting from height and weight category choices. Body mass index (BMI) values were then calculated using the mid-point of each category choice and the standard formula: $\mathrm{BMI}=$ (weight (lbs) x 703.1)/ [Height (inches) ${ }^{2}$. For example, a driver who

\footnotetext{
${ }^{1}$ All subjects who were asked provided this information; the reduction in $\mathrm{N}$ is due to the fact that questions about height and weight were only added to the intake data collection some time after initiation.

${ }^{2}$ The informed consent process made it clear to subjects that data collected was going only to academic researchers authorized by the University of Minnesota, and would never be shared with their employer; we believe this improved the likelihood of honest responses.
} 
self-reported his height as five feet and 8 to 9 inches and weight as between 160 and 180 pounds was assigned a BMI of $(170 \times 703.1) /[68.5]^{2}$ or 25.5. Because most self-reports err on the side of taller heights and lower weights, this methodology for estimating BMI is quite conservative and tends to underestimate BMI. We defined BMI categories as per the World Health Organization (WHO): (Underweight $=\mathrm{BMI}<18.5$; Normal $=18.5<\mathrm{BMI}<25.0$;

Overweight $=25 \leq \mathrm{BMI}<30$; Obese Class I $=30 \leq \mathrm{BMI}<35$; Obese Class II $=35 \leq \mathrm{BMI}<40$; Obese Class III $=\mathrm{BMI} \geq 40$.

\subsection{DRIVING EXPOSURE AND OCCUPATIONAL COVARIATES}

A significant advantage in using internal administrative data from a firm is that we have information on relevant occupational covariates that capture how the exposure to risk varies: miles driven, trip segments and job type, duties and working conditions for each participant. These data were collected on a weekly basis from the firm's records for each participant until end of the follow-up period in August, 2008 and are cumulated to a single summary record for each driver for our initial analysis, while being retained in a driver-week form for our most sophisticated statistical models.

\subsection{CRAsh Outcomes Assessment}

A second significant advantage of working with a large trucking firm is that we have information regarding all accidents, including very minor ones, and we also have more details about each accident event than are usually available. Using some of the information that managers collect about each accident event, the firm categorizes accidents according to the "potential severity" of the accident. Potentially severe accidents are ones which could easily cause significant personal injury or property damage, independent of the actual outcome. This increases the number of accidents that are potentially severe as compared to those that are actually severe, which gives us a better chance of identifying important predictors.

Initially we analyze crash risk using the most inclusive definition of a crash provided by the firm's administrative data, namely all crashes, of any potential severity--from scratches to violent collisions. Our second crash definition includes only crashes of moderate to high 
potential severity. Finally, at the furthest extreme, we consider crashes that are sufficiently (actually) severe must be reported to the United States Department of Transportation (DOT). Such "DOT reportable crashes" occur if any of the following conditions are met: an involved vehicle cannot leave under its own power, someone involved requires medical attention away from the crash scene, or there is a fatality.

\subsection{STATISTICAL ANALYSIS}

We begin by computing crash rates per 100,000 miles driven for each of six WHOdefined BMI categories. Finding initial signs of a relationship, we then analyze crash counts using a Poisson regression model (Agresti 2002) with the BMI categories as predictor variables of primary interest, cumulative miles as an exposure adjustment, and demographic factors as control variables. This produces similar findings to the unconditional estimates. Finally, in our most sophisticated approach we model the event history of crashes with the Cox proportional hazards model, using the Andersen-Gill variant which permits more than one failure event (crash) per subject (Therneau and Grambsch 2000). In this approach, the time until a crash (job tenure in weeks) is assumed to have a hazard, or risk function with two components: an underlying risk function shared by all drivers, and a risk adjustment function that depends on the characteristics of individual drivers and their operational settings week by week. This model is run on panel data, by which we mean that the data is formatted with one observation per driver per week, rather than cumulating the evidence to one observation per driver. In this approach we can control not only for variables that are constant for each driver, but also for exposure variables that can change for each driver from week to week, such as miles and trip segments per week, job type, and an indicator variable for training weeks. 


\subsection{RESULTS}

Table 1 shows the characteristics of the driver trainee subjects. The study population has an overall self-reported obesity rate (BMI $\geq 30$ ) of $33.7 \%$, which is typical of the US adult population's 33.8\% (95\% confidence interval: 31.6\%-36.0\%) during the period of 2007-08 (Flegal et al. 2010), and our subjects have a Class II and III rate of $14.65 \%$.

Table 2 gives the number of crashes per 100 drivers for each level of BMI at each crash definition, and also the crash rates per 100,000 miles for each BMI level. Considering all crashes, drivers of obesity classes II and III (BMI greater than 35) have significantly higher crash rates than drivers with normal BMI. For more severe crashes (DOT Reportable, and Moderate to Severe Crashes), which are less numerous, although drivers of obesity classes II and II have higher crash rates than drivers of normal BMI in three out of four cases, these differences are not statistically significant.

Table 3 summarizes the estimated BMI incidence rate ratios from a Poisson regression model in which the data is formatted with one observation per driver, and crashes and miles are cumulated over the full period of observation for each driver. The dependent variable is crash events per driver, and the model adjusts for total miles operated, gender, and age. Considering all crashes, we find statistical evidence that obesity classes II and III (BMI $\geq 35)$ are associated with increased accident risk compared to drivers with normal BMI, after adjusting for miles driven, gender, and age. Drivers of obesity class II ( $35 \leq \mathrm{BMI} \leq 40)$ have an adjusted incidence risk ratio of 1.60 times that of a driver with normal BMI. Drivers in obesity class III $(\mathrm{BMI} \geq 40)$ also show evidence of increased crash risk: 1.49 times that of drivers with normal BMI. The pattern for the smaller number of more severe crashes is similar to that in Table 2: in three out of four comparisons drivers of obesity classes II and III have higher incidence rates, but these differences are not statistically significant.

Table 4 presents the results from the multivariate Cox proportional hazard model. Considering all accidents, when we add time-varying exposure controls by using this model the estimates continue to show evidence that obesity class II $(35 \leq \mathrm{BMI}<40)$ is associated with a statistically significant increased accident risk compared to drivers with normal BMI, with an adjusted crash risk of 1.47 times that of a driver with normal BMI. Drivers in obesity class III 
$(\mathrm{BMI} \geq 40)$ are estimated to have 1.35 times the crash risk of drivers with normal $\mathrm{BMI}$, although this result is not statistically significant at the conventional $5 \%$ level $(P=0.06)$.

In the third column of Table 4 we utilize a different aspect of the trucking firm's administrative data: the fact that only some crashes are deemed preventable. Following the guidelines specified by the Federal Motor Carrier Safety Administration (FMCSA), for each crash the firm determines whether the driver could and should have reasonably taken actions to avoid the crash event ("preventable"), or if that was not possible under the circumstances ("not preventable") (Federal Motor Carrier Safety Administration 1991). The category of "preventable" is not the same as the legal determination that a driver was "at fault"; the former is in most cases broader than the latter. Using our most sophisticated model to consider accidents of all potential severity levels, but restricting ourselves to only those judged preventable, we find that the results on $\mathrm{BMI}$ and accident risk remain qualitatively similar to our earlier analyses. We find an increased crash risk for obesity Class II (risk ratio of 1.63) compared to drivers with normal BMI, and suggestive evidence of increased crash risk for obesity Class III (risk ratio of 1.44) compared to drivers of normal BMI, although the latter result is not statistically significant at the conventional $5 \%$ level $(P=0.06)$.

All of our models fail to show statistically significant increases in accident risk for obese drivers when the dependent variable counts crashes that are DOT reportable, or moderate to severe in potential severity, which could be due simply to the smaller numbers in these two event categories. However, it is these smaller but more severe event categories which are critical from a both a managerial and a public safety perspective. To address this issue we added a variable for the total number of previous crashes (of any severity) to the multivariate Cox proportional hazard model described above, which provided the results in Table 4 . In this augmented model we find that an additional prior accident of any severity level increases the estimated risk by a ratio of $1.13(P<0.01)$ when the dependent variable is all crashes, and by a ratio of $1.18(P<0.01)$ when the dependent variable is moderate to severe crashes, which are both very statistically significant by conventional standards. A prior accident increased risk by a ratio of 1.15 when the dependent variable counts the smaller number of DOT reportable crashes, which is qualitatively similar, although this is not significant by conventional standards 
$(P=0.12)$. Thus, it appears that an additional previous crash substantially increases the instantaneous risk of a crash of one of the more severe categories in the current period, even after adjusting for the control variables in the model, including BMI. And this addition does not remove the separate effect of obesity: In these augmented models, the BMI risk ratio estimates are very similar in magnitude, direction, and statistical significance to those reported in Table 4. These results are available from the authors upon request.

\section{DISCUSSION}

Obesity has become one of the biggest and most rapidly growing health problems in the world with numerous consequences and influences on population health. Using a variety of statistical approaches we find consistent evidence that commercial truck drivers with a BMI $\geq 35$ have increased crash risk. Using our broadest definition of an accident, this relationship is evident for analyses both with and without controlling for relevant demographic variables and relevant variations in operational factors that affect the exposure of drivers to accident risk. Estimated effects range from a $47 \%$ increase in risk (risk ratio of 1.47 ) to $63 \%$ (risk ratio of 1.63 ). When we consider less frequent categories of crashes that are more severe, we have insufficient evidence to directly establish a relationship between BMI and crash risk. This could be due to insufficient statistical power to detect the relationship, or it could be that higher BMI puts drivers at increased risk for only less severe crashes. Without a larger data set we cannot distinguish these explanations with full confidence. However, by examining a multivariate Cox proportional hazards model run on panel data (one observation per driver per work week) that included the number of previous crashes as predictor variable, we found evidence of a statistical linkage between higher BMI and more severe crashes through a two step connection. First, there was a significant relationship between $\mathrm{BMI}$ and crashes of all severity, and then second, a significant relationship between an additional past crash and a later crash of higher severity.

There are several possible explanations that could provide some insight as to why obesity is associated with an increased crash risk. First there is an increase in co-morbid conditions among obese drivers. Obstructive sleep apnea (OSA) is strongly associated with 
obesity and what is more, increased BMI is considered the principal risk factor for OSA. Sleep apnea often causes excessive daytime sleepiness (EDS). Moreover, excessive daytime sleepiness is a frequent complaint of obese patients even if they do not have sleep apnea which may be attributable to metabolic and circadian abnormalities related to obesity (Vgontzas et al. 1998). The prevalence of excessive daytime sleepiness appears to have more than doubled in the general population along with obesity rates. A study by Bixler et al. (2005) found that $10 \%$ of the general population reported experiencing moderate to severe EDS in 2005, compared with only 4\% reported in a 1979 survey. The same 2005 study demonstrated that obesity was a significant risk factor for EDS independent of OSA and age, in agreement with other crosssectional investigations (Resta et al. 2001, Resta et al. 2003). Finally, obese drivers may be limited by their body habitus with regard to their mobility within the truck cab and ability to react to certain hazards compared to leaner colleagues.

Our findings are in general agreement with evidence from population studies that increased body weight is associated with increased risk of mortality and increased risk of severe injury in motor vehicle accidents (Mock et al. 2002, Whitlock et al. 2003, Zhu et al. 2006, Viano et al. 2008). More closely related to the present study, a study by Wiegand et al. (2009) explored the association between commercial truck driver's BMI and fatigue-related safetycritical events. The results were supportive of a link between obesity, fatigue and a greater risk for involvement in safety-critical incidents and highlight the fact that obesity is an important safety issue in commercial motor vehicle operators. Furthermore, a study by Stoohs et al. (1994) in long-haul truck drivers reported that obese drivers were falling asleep unintentionally more often that non-obese drivers and were more likely to be involved in motor vehicle accidents.

Limitations of the present study are that we had access only to the new hires of the truckload (TL) motor carrier we worked with who were newly trained and thus more prone to making driving and maneuvering mistakes than experienced drivers. While this is an important subpopulation among heavy commercial vehicle drivers ${ }^{3}$, our subjects are not a representative

\footnotetext{
${ }^{3}$ Drivers in the type of firm studied (TL carriers) are of public policy interest because they make up the largest single segment of commercial drivers operating heavy tractor trailers on U.S. highways (more than .5 million of the approximately 2.0 million total), and-as mentioned in Section 2.1, high turnover in this segment (typically
}

Page 12 of 21 
sample of the whole population. Another issue is that BMI was based on self-reported values for height and weight and thus, as research has shown, some of the responders might have a tendency to overestimate their height and underestimate their weight. However, because this bias tends to underreport $\mathrm{BMI}$ it makes it harder, not easier, to find the results we present. To further mitigate this problem we used the midpoints of the category ranges, thus calculating BMI's conservatively. As a result, the increased crash risk for a motor vehicle crash we observe at BMI values of 35 and above may actually begin between 30 and 35 . Finally, we did not have access to additional medical information on the drivers, which limits our ability to draw inferences regarding the mechanisms that increase crash among obese drivers, although this does not affect our evidence for an association between obesity and crashes.

Strengths of this study are that our data are prospective and we followed each driver after initial intake for two years (or until separation), using the firm's human resource and operational data. In addition, and most importantly, we had full access to internal administrative accident data, not self-reported crash information, and which means we have full information on all accidents including very minor ones, independent of the actual outcome and severity of the accident. This allows us to use the firm's assignment of a "potential severity" category to each accident, which overcomes the limitation of using data collected from governmental sources in which crashes are only reported if there is significant personal injury or property damage involved. Our use of firm's assignment of a "non-preventable versus preventable" category overcomes the corresponding limitation of government data in which either no such information is available, or only a narrower "driver at fault" category is used. Moreover, through access to the firm's internal data we had the ability to identify all the occupational covariates and statistically important job-related predictors that affect how exposure to risk varies across drivers and over time, thus controlling for many potentially important confounding factors which other studies are unable to address.

over $100 \%$ per year during non-recession years) makes new hires always a significant proportion of this subpopulation; (Monaco, K., Burks, S.V., 2011. The trucking industry. In: Hoel, L., Giuliano, G., Meyer, M. eds. Intermodal freight transportation: Moving freight in a global economy. Eno Transportation Foundation, Washington, DC.). 


\section{CONCLUSION}

This prospective study establishes an association between obesity and increased crash risk among commercial drivers operating heavy freight vehicles on the public highways and thus has important implications for both drivers' health and public safety. Further studies with larger samples, including representatives from both experienced drivers and new hires, with additional medical information on possible co-existing conditions such as OSA may help reveal more about the nature of these links.

\section{Acknowledgements}

The authors gratefully acknowledge the assistance of the executives and staff of the cooperating trucking firm, as well as financial assistance to UMM's Truckers \& Turnover Project from the cooperating firm, the MacArthur Foundation's Research Network on the Origins of Norms and Preferences, the Sloan Foundation, the Trucking Industry Program (Georgia Tech), and the University of Minnesota Morris. Errors remain the responsibility of the authors. 
Table 1: Descriptive Demographic and Anthropometric Characteristics of the 744 study participants

\begin{tabular}{|c|c|c|}
\hline Variable & Frequency & Percent \\
\hline \multicolumn{3}{|l|}{ Sex } \\
\hline Male & 667 & 89.65 \\
\hline Female & 77 & 10.35 \\
\hline \multicolumn{3}{|l|}{ Marital Status } \\
\hline Married & 356 & 47.85 \\
\hline Separated & 29 & 3.90 \\
\hline Divorced & 129 & 17.34 \\
\hline Single, Never Married & 230 & 30.91 \\
\hline \multicolumn{3}{|l|}{ Education } \\
\hline Less Than High School & 28 & 3.76 \\
\hline High School & 297 & 39.92 \\
\hline Some College & 356 & 47.85 \\
\hline Bachelor's Degree or more & 63 & 8.47 \\
\hline \multicolumn{3}{|l|}{ Race } \\
\hline White & 638 & 85.87 \\
\hline Non-White & 105 & 14.13 \\
\hline \multicolumn{3}{|l|}{ BMI } \\
\hline Underweight BMI < 18.5 & 22 & 2.96 \\
\hline Normal $18.5<\mathrm{BMI}<25.0$ & 244 & 32.80 \\
\hline Overweight $25 \leq \mathrm{BMI}<30$ & 227 & 30.51 \\
\hline Obese: Class I $30 \leq \mathrm{BMI}<35$ & 142 & 19.09 \\
\hline Obese: Class II $35 \leq \mathrm{BMI}<40$ & 50 & 6.72 \\
\hline Obese: Class III BMI $\geq 40$ & 59 & 7.93 \\
\hline \multicolumn{3}{|l|}{ Job Type } \\
\hline $\begin{array}{l}\text { OTR Long haul irregular route work; the } \\
\text { archetypal truckload }(\mathrm{TL}) \text { job }\end{array}$ & 210 & 28.23 \\
\hline $\begin{array}{l}\text { Shared Truck Three drivers share a tractor with } \\
\text { guaranteed time at home }\end{array}$ & 12 & 1.61 \\
\hline $\begin{array}{l}\text { Intermodal Drayage work moving trailers } \\
\text { between customers and rail or marine } \\
\text { transportation terminals; usually regional or local }\end{array}$ & 28 & 3.76 \\
\hline Driver Team Two drivers in the same truck & 45 & 6.05 \\
\hline OTR Dedicated Long haul for a specific customer & 157 & 21.10 \\
\hline $\begin{array}{l}\text { Regional Dedicated Regional for a specific } \\
\text { customer }\end{array}$ & 55 & 7.39 \\
\hline $\begin{array}{l}\text { Other Dedicated For a specific customer, in some } \\
\text { way not already described }\end{array}$ & 33 & 4.44 \\
\hline Job Type: Missing Missing data for given week & 204 & 27.42 \\
\hline
\end{tabular}

$\mathrm{BMI}=$ body mass index; OTR= over the road 
Table 2: Crash Numbers and Rates per 100,000 miles by BMI Category.

Significance denoted $*(p<0.05)$ or $* *(p<0.01)$ is higher than for Normal BMI (BMI 18.5 to 25$)$.

\begin{tabular}{|c|c|c|c|c|c|c|}
\hline \multirow[t]{2}{*}{ BMI } & \multicolumn{2}{|c|}{ DOT reportable crashes } & \multicolumn{2}{|c|}{$\begin{array}{c}\text { Moderate to severe } \\
\text { crashes }\end{array}$} & \multicolumn{2}{|c|}{ All crashes } \\
\hline & $\begin{array}{l}\text { Number of } \\
\text { crashes } \\
\text { (per } 100 \\
\text { drivers) }\end{array}$ & $\begin{array}{c}\text { Crash Rate } \\
\text { (per } \\
100,000 \\
\text { miles) }\end{array}$ & $\begin{array}{l}\text { Number of } \\
\text { crashes } \\
\text { (per } 100 \\
\text { drivers) }\end{array}$ & $\begin{array}{c}\text { Crash Rate } \\
\text { (per } \\
100,000 \\
\text { miles) }\end{array}$ & $\begin{array}{l}\text { Number of } \\
\text { crashes } \\
\text { (per } 100 \\
\text { drivers) }\end{array}$ & $\begin{array}{c}\text { Crash Rate } \\
\text { (per } \\
100,000 \\
\text { miles) }\end{array}$ \\
\hline $\begin{array}{l}\text { Underweight } \\
\mathrm{BMI}<18.5\end{array}$ & 9 & .138 & 36 & .552 & 114 & 1.724 \\
\hline $\begin{array}{c}\text { Normal } \\
18.5 \leq \mathrm{BMI} \\
<25.0\end{array}$ & 9 & .160 & 27 & .452 & 82 & 1.385 \\
\hline $\begin{array}{c}\text { Overweight } \\
25 \leq \mathrm{BMI}< \\
30\end{array}$ & 8 & .123 & 24 & .357 & 98 & 1.446 \\
\hline $\begin{array}{c}\text { Obese: } \\
\text { class I } \\
30 \leq \mathrm{BMI}< \\
35\end{array}$ & 10 & .153 & 25 & .393 & 94 & 1.450 \\
\hline $\begin{array}{c}\text { Obese: } \\
\text { class II } \\
35 \leq \mathrm{BMI}< \\
40\end{array}$ & 20 & .309 & 38 & .586 & 142 & $2.191 * *$ \\
\hline $\begin{array}{c}\text { Obese: } \\
\text { class III } \\
\text { BMI } \geq 40\end{array}$ & 7 & .122 & 27 & .487 & 107 & 1.917 * \\
\hline
\end{tabular}

$\mathrm{BMI}=$ body mass index; DOT= department of transportation; parentheses give $95 \%$ confidence interval 
Table 3: Poisson Regression Risk Ratios (control variables included, but coefficients omitted).

\begin{tabular}{|c|c|c|c|}
\hline $\begin{array}{l}\text { Body Mass } \\
\text { Index }\end{array}$ & $\begin{array}{l}\text { DOT Reportable } \\
\text { Crashes }\end{array}$ & $\begin{array}{l}\text { Moderate to } \\
\text { Severe Crashes }\end{array}$ & All Crashes \\
\hline $\begin{array}{l}\text { Underweight } \\
B M I<18.5\end{array}$ & $\begin{array}{c}0.860 \\
P=.838 \\
(0.201,3.674)\end{array}$ & $\begin{array}{c}1.258 \\
P=0.543 \\
(0.600,2.636)\end{array}$ & $\begin{array}{c}1.332 \\
P=0.180 \\
(0.876,2.024)\end{array}$ \\
\hline $\begin{array}{l}\text { Normal } \\
18.5 \leq B M I< \\
25.0\end{array}$ & $\begin{array}{l}\text { reference } \\
\text { category }\end{array}$ & $\begin{array}{l}\text { reference } \\
\text { category }\end{array}$ & $\begin{array}{l}\text { reference } \\
\text { category }\end{array}$ \\
\hline $\begin{array}{l}\text { Overweight } \\
25 \leq B M I<30\end{array}$ & $\begin{array}{c}0.834 \\
P=.564 \\
(0.451,1.544)\end{array}$ & $\begin{array}{c}0.832 \\
P=0.322 \\
(0.578,1.198)\end{array}$ & $\begin{array}{c}1.068 \\
P=0.505 \\
(0.880,1.296)\end{array}$ \\
\hline $\begin{array}{l}\text { Obese: Class I } \\
30 \leq B M I<35\end{array}$ & $\begin{array}{c}1.093 \\
P=.798 \\
(0.554,2.156)\end{array}$ & $\begin{array}{c}0.967 \\
P=0.874 \\
(0.638,1.466)\end{array}$ & $\begin{array}{c}1.067 \\
P=0.570 \\
(0.853,1.335)\end{array}$ \\
\hline $\begin{array}{l}\text { Obese: Class II } \\
35 \leq B M I<40\end{array}$ & $\begin{array}{c}1.574 \\
P=.241 \\
(0.737,3.362)\end{array}$ & $\begin{array}{c}1.279 \\
P=0.356 \\
(0.759,2.156)\end{array}$ & $\begin{array}{c}1.604 \\
P=0.001 \\
(1.216,2.117)\end{array}$ \\
\hline $\begin{array}{l}\text { Obese: Class III } \\
B M I \geq 40\end{array}$ & $\begin{array}{c}0.799 \\
P=.682 \\
(0.273,2.336)\end{array}$ & $\begin{array}{c}1.248 \\
P=0.453 \\
(0.716,2.174)\end{array}$ & $\begin{array}{c}1.493 \\
P=0.006 \\
(1.119,1.992)\end{array}$ \\
\hline
\end{tabular}

Note: parentheses contain the $95 \%$ confidence interval of the estimate. 
Table 4: Multivariate Panel Cox Proportional Hazard Model Risk Ratios (control variables included but coefficients omitted).

\begin{tabular}{|c|c|c|}
\hline BMI & All Crashes & $\begin{array}{c}\text { Preventable } \\
\text { Crashes }\end{array}$ \\
\hline $\begin{array}{l}\text { Underweight } \\
B M I<18.5\end{array}$ & $\begin{array}{c}1.258 \\
P=.0242 \\
(0.857,1.849)\end{array}$ & $\begin{array}{c}1.192 \\
P=0.464 \\
(0.745,1.908)\end{array}$ \\
\hline $\begin{array}{c}\text { Normal } \\
18.5 \leq \mathrm{BMI}<25.0\end{array}$ & reference category & reference category \\
\hline $\begin{array}{c}\text { Overweight } \\
25 \leq B M I<30\end{array}$ & $\begin{array}{c}1.126 \\
P=0.257 \\
(0.917,1.381)\end{array}$ & $\begin{array}{c}1.173 \\
P=0.230 \\
(0.904,1.522)\end{array}$ \\
\hline $\begin{array}{l}\text { Obese: Class I } \\
30 \leq B M I<35\end{array}$ & $\begin{array}{c}1.048 \\
P=0.712 \\
(0.817,1.345)\end{array}$ & $\begin{array}{c}1.127 \\
P=0.465 \\
(0.817,1.555)\end{array}$ \\
\hline $\begin{array}{l}\text { Obese: Class II } \\
35 \leq B M I<40\end{array}$ & $\begin{array}{c}1.470 \\
P=0.020 \\
(1.062,2.034)\end{array}$ & $\begin{array}{c}1.632 \\
P=0.019 \\
(1.084,2.455)\end{array}$ \\
\hline $\begin{array}{c}\text { Obese: Class III } \\
\qquad B M I \geq 40\end{array}$ & $\begin{array}{c}1.351 \\
P=0.059 \\
(0.988,1.848)\end{array}$ & $\begin{array}{c}1.438 \\
P=0.060 \\
(0.985,2.100)\end{array}$ \\
\hline
\end{tabular}

Note: parentheses contain the $95 \%$ confidence interval of the estimate. 


\section{References}

Agresti, A., 2002. Categorical data analysis, 2nd ed. Wiley-Interscience, Hoboken, NJ.

Berrington De Gonzalez, A., Hartge, P., Cerhan, J.R., Flint, A.J., Hannan, L., Macinnis, R.J., Moore, S.C., Tobias, G.S., Anton-Culver, H., Freeman, L.B., Beeson, W.L., Clipp, S.L., English, D.R., Folsom, A.R., Freedman, D.M., Giles, G., Hakansson, N., Henderson, K.D., Hoffman-Bolton, J., Hoppin, J.A., Koenig, K.L., Lee, I.M., Linet, M.S., Park, Y., Pocobelli, G., Schatzkin, A., Sesso, H.D., Weiderpass, E., Willcox, B.J., Wolk, A., Zeleniuch-Jacquotte, A., Willett, W.C., Thun, M.J., 2010. Body-mass index and mortality among 1.46 million white adults. N Engl J Med 363 (23), 2211-9.

Bixler, E.O., Vgontzas, A.N., Lin, H.M., Calhoun, S.L., Vela-Bueno, A., Kales, A., 2005. Excessive daytime sleepiness in a general population sample: The role of sleep apnea, age, obesity, diabetes, and depression. Journal of Clinical Endocrinology and Metababolism 90 (8), 4510-5.

Burks, S., Carpenter, J., Götte, L., Monaco, K., Porter, K., Rustichini, A., 2008. Using behavioral economic field experiments at a firm: The context and design of the truckers and turnover project. In: Bender, S., Lane, J., Shaw, K., Andersson, F., Von Wachter, T. eds. The analysis of firms and employees: Quantitative and qualitative approaches. NBER and University of Chicago pp. 45106.

Burks, S.V., 2009a. Are you smart enough to drive a truck? Transport Topics (July 27), 9.

Burks, S.V., Belzer, M., Kwan, Q., Pratt, S., Shackelford, S., 2010. Trucking 101: An industry primer. Transportation Research Circular Number E-C146. Transportation Research Board, Washington, DC.

Burks, S.V., Carpenter, J., Götte, L., Rustichini, A., 2009b. Cognitive skills affect economic preferences, social awareness, and job attachment. Proceedings of the National Academy of Science 106 (19), 7745-7750.

Calle, E.E., Rodriguez, C., Walker-Thurmond, K., Thun, M.J., 2003. Overweight, obesity, and mortality from cancer in a prospectively studied cohort of u.S. Adults. N Engl J Med 348 (17), 1625-38.

Cohen, D.A., Wang, W., Wyatt, J.K., Kronauer, R.E., Dijk, D.J., Czeisler, C.A., Klerman, E.B., 2010. Uncovering residual effects of chronic sleep loss on human performance. Sci Transl Med 2 (14), 14 ra3.

Dagan, Y., Doljansky, J.T., Green, A., Weiner, A., 2006. Body mass index (bmi) as a first-line screening criterion for detection of excessive daytime sleepiness among professional drivers. Traffic Inj Prev 7 (1), 44-8.

Dinges, D.F., Pack, F., Williams, K., Gillen, K.A., Powell, J.W., Ott, G.E., Aptowicz, C., Pack, A.I., 1997. Cumulative sleepiness, mood disturbance, and psychomotor vigilance performance decrements during a week of sleep restricted to 4-5 hours per night. Sleep 20 (4), 267-77.

Dixon, J.B., Dixon, M.E., Anderson, M.L., Schachter, L., O'brien P, E., 2007. Daytime sleepiness in the obese: Not as simple as obstructive sleep apnea. Obesity (Silver Spring) 15 (10), 2504-11.

Eckel, R.H., Kahn, S.E., Ferrannini, E., Goldfine, A.B., Nathan, D.M., Schwartz, M.W., Smith, R.J., Smith, S.R., 2011. Obesity and type 2 diabetes: What can be unified and what needs to be individualized? J Clin Endocrinol Metab 96 (6), 1654-63.

Economic and Statistics Group, 2007. Truckload line-haul driver turnover quarterly annualized rates. Trucking Activity Report. American Trucking Associations, pp. 1.

Federal Motor Carrier Safety Administration, 1991. Accident preventability evaluations. Accident countermeasures manual. U.S. Department of Transportation, Washington, DC.

Finucane, M.M., Stevens, G.A., Cowan, M.J., Danaei, G., Lin, J.K., Paciorek, C.J., Singh, G.M., Gutierrez, H.R., Lu, Y., Bahalim, A.N., Farzadfar, F., Riley, L.M., Ezzati, M., 2011. National, regional, and global trends in body-mass index since 1980: Systematic analysis of health examination surveys 
and epidemiological studies with 960 country-years and 9.1 million participants. Lancet 377 (9765), 557-67.

Flegal, K.M., Carroll, M.D., Ogden, C.L., Curtin, L.R., 2010. Prevalence and trends in obesity among us adults, 1999-2008. JAMA 303 (3), 235-41.

Garbarino, S., Nobili, L., Beelke, M., De Carli, F., Ferrillo, F., 2001. The contributing role of sleepiness in highway vehicle accidents. Sleep 24 (2), 203-6.

Gurubhagavatula, I., 2010. Consequences of obstructive sleep apnoea. Indian J Med Res 131 (February), 188-95.

Gurubhagavatula, I., Maislin, G., Nkwuo, J.E., Pack, A.I., 2004. Occupational screening for obstructive sleep apnea in commercial drivers. Am J Respir Crit Care Med 170 (4), 371-6.

Hartenbaum, N., Collop, N., Rosen, I.M., Phillips, B., George, C.F., Rowley, J.A., Freedman, N., Weaver, T.E., Gurubhagavatula, I., Strohl, K., Leaman, H.M., Moffitt, G.L., Rosekind, M.R., 2006. Sleep apnea and commercial motor vehicle operators: Statement from the joint task force of the american college of chest physicians, american college of occupational and environmental medicine, and the national sleep foundation. J Occup Environ Med 48 (9 Suppl), S4-37.

Mock, C.N., Grossman, D.C., Kaufman, R.P., Mack, C.D., Rivara, F.P., 2002. The relationship between body weight and risk of death and serious injury in motor vehicle crashes. Accident; analysis and prevention 34 (2), 221-8.

Monaco, K., Burks, S.V., 2011. The trucking industry. In: Hoel, L., Giuliano, G., Meyer, M. eds. Intermodal freight transportation: Moving freight in a global economy. Eno Transportation Foundation, Washington, DC.

Ntsb, 1999. Evaluation of u.S. Department of transportation efforts in the 1990s to address operator fatigue.

Pack, A., Dinges, D., Maislin, G., 2002. A study of prevalence of sleep apnea among commercial truck drivers. FMCSA, Publication No. DOT-RT-02-030.

Pack, A.I., Maislin, G., Staley, B., Pack, F.M., Rogers, W.C., George, C.F., Dinges, D.F., 2006. Impaired performance in commercial drivers: Role of sleep apnea and short sleep duration. Am J Respir Crit Care Med 174 (4), 446-54.

Parks, P., Durand, G., Tsismenakis, A.J., Vela-Bueno, A., Kales, S., 2009. Screening for obstructive sleep apnea during commercial driver medical examinations. J Occup Environ Med 51 (3), 275-82.

Philip, P., 2005. Sleepiness of occupational drivers. Ind Health 43 (1), 30-3.

Resta, O., Caratozzolo, G., Pannacciulli, N., Stefàno, A., Giliberti, T., Carpagnano, G.E., De Pergola, G., 2003. Gender, age and menopause effects on the prevalence and the characteristics of obstructive sleep apnea in obesity. European Journal of Clinical Investigation 33 (12), 1084-9.

Resta, O., Foschino-Barbaro, M.P., Legari, G., Talamo, S., Bonfitto, P., Palumbo, A., Minenna, A., Giorgino, R., De Pergola, G., 2001. Sleep-related breathing disorders, loud snoring and excessive daytime sleepiness in obese subjects. Int J Obes Relat Metab Disord 25 (5), 669-75.

Stoohs, R.A., Guilleminault, C., Itoi, A., Dement, W.C., 1994. Traffic accidents in commercial long-haul truck drivers: The influence of sleep-disordered breathing and obesity. Sleep 17 (7), 619-23.

Talmage, J.B., Hudson, T.B., Hegmann, K.T., Thiese, M.S., 2008. Consensus criteria for screening commercial drivers for obstructive sleep apnea: Evidence of efficacy. J Occup Environ Med 50 (3), 324-9.

Teran-Santos, J., Jimenez-Gomez, A., Cordero-Guevara, J., 1999. The association between sleep apnea and the risk of traffic accidents. Cooperative group burgos-santander. N Engl J Med 340 (11), 847-51.

Therneau, T.M., Grambsch, P.M., 2000. Modeling survival data: Extending the cox model Springer, New York, NY. 
Tregear, S., Reston, J., Schoelles, K., Phillips, B., 2009. Obstructive sleep apnea and risk of motor vehicle crash: Systematic review and meta-analysis. J Clin Sleep Med 5 (6), 573-81.

Vgontzas, A.N., 2008a. Does obesity play a major role in the pathogenesis of sleep apnoea and its associated manifestations via inflammation, visceral adiposity, and insulin resistance? Arch Physiol Biochem 114 (4), 211-23.

Vgontzas, A.N., 2008b. Excessive daytime sleepiness in sleep apnea: It is not just apnea hypopnea index. Sleep Med 9 (7), 712-4.

Vgontzas, A.N., Bixler, E.O., Tan, T.L., Kantner, D., Martin, L.F., Kales, A., 1998. Obesity without sleep apnea is associated with daytime sleepiness. Archives of internal medicine 158 (12), 1333-7.

Viano, D.C., Parenteau, C.S., Edwards, M.L., 2008. Crash injury risks for obese occupants using a matched-pair analysis. Traffic injury prevention 9 (1), 59-64.

Watson, R., 2009. Driver turnover rate rises. Transport Topics (Sept. 27), 1.

Whitlock, G., Norton, R., Clark, T., Jackson, R., Macmahon, S., 2003. Is body mass index a risk factor for motor vehicle driver injury? A cohort study with prospective and retrospective outcomes. International journal of epidemiology 32 (1), 147-9.

Who, 2000. Obesity: Preventing and managing the global epidemic World Health Organization, Geneva.

Wiegand, D.M., Hanowski, R.J., Mcdonald, S.E., 2009. Commercial drivers' health: A naturalistic study of body mass index, fatigue, and involvement in safety-critical events. Traffic injury prevention 10 (6), 573-9.

Zhu, S., Layde, P.M., Guse, C.E., Laud, P.W., Pintar, F., Nirula, R., Hargarten, S., 2006. Obesity and risk for death due to motor vehicle crashes. American journal of public health 96 (4), 734-9. 